\title{
PENGARUH METODE BERCERITA MENGGUNAKAN PANGGUNG BONEKA TERHADAP KEMAMPUAN MENYIMAK ANAK KELOMPOK B1 TK NEGERI PEMBINA HANAU DI DESA PEMBUANG HULU KECAMATAN HANAU KABUPATEN SERUYAN KALIMATAN TENGAH TAHUN AJARAN 2019
}

\author{
Rusnul Jamilah \\ Program Studi PG PAUD FKIP Universitas Palangka Raya \\ Jl. H. Timang Komplek Kampus Tunjung Nyaho Palangka Raya \\ Email : jamilahrusnul@gmail.com
}

\begin{abstract}
ABSTRAK
Menyimak adalah kegiatan mendengarkan secara aktif dan kreatif untuk memperoleh informasi, menangkap isi cerita atau pesan serta memahami makna komunikasi yang disampaikan secara lisan. Manfaat kegiatan metode bercerita menggunakan panggung boneka yang merupakan persiapan awal atau pengenalan kemampuan mendengar anak. Kegiatan bercerita menggunakan panggung boneka bermanfaat untuk mengembangkan kemampuan menyimak anak dalam keterampilan mendengar anak. Penelitian ini melibatkan 18 orang anak di kelompok B1 TK Negeri pembina hanau di pembuang hulu kecamatan hanau kabupaten seruyan. Data dijaring menggunakan observasi dalam bentuk penilaian, dan dukomentasi, serta dianalisis dengan teknik statistik uji-t. Tujuan dari penelitian ini untuk mengetahui Pengaruh Metode Bercerita Menggunakan Panggung Boneka Terhadap Kemampuan Menyimak Anak.

Hasil penelitian diperoleh dari perhitungan uji-t diperoleh nilai $t_{\text {hitung }}$ sebesar 4,181 dengan taraf signifikan 5\% dan db $(N-1=18-1=17)$ maka nilai $t_{\text {tabel }}$ adalah 2,110, dapat diketahui bahwa $t_{\text {hitung }}>t_{\text {tabel }}$ yaitu $t_{\text {hitung }}=$ 4,181> $t_{\text {tabel }}=2,110$. Jika $t_{\text {hitung }}>t_{\text {tabel, }}$ maka $H_{a}$ dapat diterima, dan $H_{o}$ ditolak, artinya ada pengaruh yang positif penggunaan media panggung boneka terhadap Kemampuan Menyimak Anak Kelompok B1 Tk Negeri Pembina Hanau Di Desa Pembuang Hulu Kecamatan Hanau Kabupaten Seruyan tahun ajaran 2018/2019.
\end{abstract}

Kata kunci : Menyimak, Metode Bercerita, Panggung Boneka. 


\section{PENDAHULUAN}

Pendidikan anak usia dini (PAUD) merupakan pendidikan yang sangat penting, karena pendidikan anak usia dini adalah pendidikan dasar yang menjadi landasan untuk melanjutkan kejenjang yang lebih tinggi lagi. Pendidikan hendaknya harus ditanamkan kepada setiap individu agar tercapainya suatu kemajuan bangsa yang lebih berkualitas sehingga tercapainya sebuah kesejahteraan dalam taraf kehidupan masyarakat indonesia. Menurut Berk dalam Sujiono (2013:6). "Pada masa ini proses pertumbuhan dan perkembangan dalam berbagai aspek sedang mengalami masa yang cepat dalam rentang perkembangan hidup manusia”. Proses pembelajaran sebagai bentuk perilaku yang diberikan pada anak harus memperhatikan karakteristrik yang dimiliki setiap tahapan perkembangan.(Sujiono:2013)

Dhieni (2005:6.6) menyatakan bahwa :"Metode bercerita adalah cara penyampaikan atau penyajikan materi pembelajaran secara lisan dalam bentuk cerita dari guru kepada anak didik Taman Kanak- kanak. Metode bercerita dilaksanakan dalam upaya memperkenalkan memberikan keterangan, atau penjelasan tentang hal baru dalam rangka menyampaikan pembelajaran yang dapat mengembangkan berbagai kompetensi dasar anak Tanam Kanakkanak". Dhieni (2005:6.4) "Bercerita adalah suatu kegiatan yang dilakukan seseroang secara lisan kepada orang lain dengan alat atau tanpa alat tentang apa yang harus disampaikan dalam bentuk pesan, informasi atau hanya sebuah dongeng yang untuk didengarkan dengan rasa menyenangkan, oleh karena orang yang menyajikan cerita tersebut menyampaikannya dengan menarik".

Panggung boneka adalah merupakan suatu tempat yang digunakan untuk mementaskan atau menampilkan suatu cerita dengan tokoh-tokoh boneka yang memerankannya. Panggung boneka dapat dikategorikan dalam dua jenis yaitu panggung boneka dua dimensi dan panggung boneka tiga dimensi. Media panggung boneka sangat cocok digunakan dalam pembelajaran bahasa Indonesia karena dalam pembelajaran bahasa Indonesia terdapat keterampilan-keterampilan bahasa yang harus dikembangkan dengan media yang mampu memancing daya imajinasi siswa dan menarik perhatian siswa.

Salah satu media yang dapat digunakan dalam meningkatkan keterampilan menyimak anak adalah menggunakan panggung boneka. Sebagai media pembelajaran, becerita menggunakan panggung boneka dapat menjadi media untuk menggembangkan 
daya pikir anak, mengembangkan daya visual anak, serta anak dapat menggembangkan imajinasi dengan pembelajaran yang menyenangkan.

Menyimak merupakan kegiatan komunikasi dua arah bersifat langsung dan bersifat tatap muka, melibatkan proses menginterpretasi dan menterjemahkan suara yang didengar sehingga memilih arti tertentu. Menurut Anderson dalam Dhieni (2005:4.6) "menyimak bermakna mendengarkan dengan penuh pemahaman dan perhatian serta apresiasi". Pendapat ini dipertegas oleh Taringan dalam Dhieni (2005:4.6) "bahwa menyimak adalah suatu proses kegiatan mendengarkan lambang lambang lisan dengan penuh perhatian, pemahaman, apresiasi, serta interpretasi untuk memperoleh informasi, menangkap isi atau pesan serta memahami makna komunikasi yang telah disampaikan oleh para pembicara serta makna komunikasi yang telah disampaikan oleh pembicara melalui bahasa lisan". Jadi berdasarkan pendapat-pendapat di atas dapat disimpulkan bahwa menyimak adalah kegiatan mendengarkan secara aktif dan kreatif untuk memperoleh informasi, menangkap isi cerita atau pesan serta memahami makna komunikasi yang disampaikan secara lisan.(Dhieni:2005)

Namun kenyatannya, kemampuan menyimak pada anak masih belum berkembang. Berdasarkan hasil observasi di kelompok B1 TK Negeri Pembina Hanau di Pembuang Hulu Kecamatan Hanau Kabupaten Seruyan, bahwa kemampuan menyimak anak masih belum optimal. Saat guru menanyakan tentang pembelajaran yang dijelaskan anak-anak hanya diam dan tidak bisa menjawab sebab mereka asik dengan kegiatan mereka sendiri, saat ada anak-anak yang menjawab pertanyaan gurunya dengan tebata-bata. Gurunya juga sering meminta anak untuk mengulangi kalimat yang guru ucapkan akan tetapi sebagai anak ada yang mengulagi dan ada juga yang tidak mengulagi kata-kata yang disebutkan guru tersebut. Terkadang guru juga memberikan perintah lebih dari satu perintah untuk anak misalnya mengambil buku temannya dan memberikan kepada temannya akan tetapi anak hanya mengambil buku tersebut dan tidak memberikan kepada temannya. Dari permasalahan ini peneliti tertarik untuk melakukan penelitian dengan menggunakan kegiatan metode bercerita menggunakan panggung boneka agar kemampuan anak berkembang secara optimal sesuai dengan perkembangan anak. 


\section{Bahasa}

Menurut Bromley dalam Dhieni (2005:1.11)“mendefiniskan bahwa sebagai sistem simbol yang teratur untuk mentransfer berbagai ide maupun informasi yang terdiri dari simbol-simbol visual maupun verbal". Simbol-simbol visual tersebut dapat dilihat, ditulis, dan dibaca, sedangkan simbol-simbol verbal dapat diucapkan dan didengar. Anak dapat maemanipulasi simbol-simbol tersebut dengan berbagai cara sesuai dengan kemampuan berpikirnya.(Dhieni:2005)

\section{Menyimak}

Menurut Anderson dalam Dhieni (2005:4.6)“menyimak bermakna mendengarkan dengan penuh pemahaman dan perhatian serta apresiasi”. Pendapat ini dipertegas oleh Taringan dalam Dhieni (2005:4.6)"bahwa menyimak adalah suatu proses kegiatan mendengarkan lambang-lambang lisan dengan penuh perhatian, pemahaman, apresiasi, serta interpretasi untuk memperoleh informasi, menangkap isi atau pesan serta memahami makna komunikasi yang telah disampaikan oleh para pembicara serta makna komunikasi yang telah disampaikan oleh pembicara melalui bahasa lisan". Menurut Sabarti dalam Dhieni (2005:4.6)"mengemukan bahwa menyimak adalah suatu proses yang mencakup kegiatan mendengarkan bunyi bahasa, mengidentifikasi, menginterpretasi menilai dan mereaksi atas makna yang terkandung di dalamnya". (Dhieni:2005)

\section{Media Pembelajaran}

Media berasal dari bahas latih dan merupakan bentuk jamak dari kata medium yang secara harfiah mempunyai arti antara, perantara atau pengantar. Media adalah perantara atau pengantar pesan dari pengiriman pesan ke penerima pesan. Media adalah segala sesuatu yang dapat digunakan untuk menyampaikan pesan dari pengirim pesan kepada penerima pesan sehingga dapat merangsang pikiran, perasaan dan perhatian anak didik untuk mencapainya tujuan pendidikan.(Latif dkk:2013)

\section{Media Panggung Boneka}

Panggung boneka adalah Panggung boneka adalah merupakan suatu tempat yang digunakan untuk mementaskan atau menampilkan suatu cerita dengan tokoh-tokoh 
boneka yang memerankannya. Panggung boneka dapat dikategorikan dalam dua jenis yaitu panggung boneka dua dimensi dan panggung boneka tiga dimensi.(jurnal skripsi Solihati halaman 4).

\section{Metode Bercerita}

Menurut Dhieni (2005:6.6) menyatakan bahwa :"Metode bercerita adalah cara penyampaikan atau penyajikan materi pembelajaran secara lisan dalam bentuk cerita dari guru kepada anak didik Taman Kanak-kanak". Metode bercerita dilaksanakan dalam upaya memperkenalkan memberikan keterangan, atau penjelasan tentang hal baru dalam rangka menyampaikan pembelajaran yang dapat mengembangkan berbagai kompetensi dasar anak Tanam Kanak-kanak”. (Dhieni:2005)

\section{METODE PENELITIAN}

Penelitian Ini Dilakukan Di Taman Kanak-Kanak Negeri Pembina Hanau Dipembuang Hulu 1 Kecamatan Hanau Kabupaten Seruyan Yang Berlokasi Di Jalan Baktri Entong Pembuang Hulu 1 Kecamatan Hanau, Kalimatan Tengah. Subjek Penelitian Ini Yaitu Anak Usia 5-6 Tahun Di Kempok B1 Sebanyak 18 Orang.

Sebelumnya peneliti telah melakukan wawancara dan obserbasi awal di lapangan untuk mengetahui bagaimana kemampuan menyimak anak di taman kanakkanak tersebut.Penggunaan media bercerita menggunakan panggung boneka diperoleh dengan melakukan observasi terhadap aktivitas anak mengulang kalimat yang lebih kompleks, menceritakan kembali dengan kosakata anak sendiri, melakukan beberapa perintah secara bersamaan, kegiatan treatment dilakukan 8 kali pertemuan yang bertema hewan-hewan dengan cerita yang berbeda-beda.

Berdasarkan hasil uji-t diketahui rata-rata nilai pre-test 96 setelah dilakukan post-test menjadi 121 sehingga peningkatan sebesar 25. Selanjutnya berdasarkan uji-t diperoleh hitungan nilai $t_{\text {hitung }}=4,181$ nilai at tabel dengan df 17 pada taraf 5\% adalah 2,110 menunjukkan jika $t_{\text {hitung }}>t_{\text {tabel, }}$ maka $\mathrm{H}_{\mathrm{a}}$ diterima, dan $\mathrm{H}_{\mathrm{o}}$ ditolak terjadi Pengaruh Metode Bercerita Menggunakan Panggung Boneka Terhadap Kemampuan Menyimak Anak Pada Kelompok B1 di TKN Pembina Hanau Dipembuang Hulu 1 Kecamatan Hanau Kabupaten Seruyan. Berdasarkan hal tersebut terdapat makna bahwa 
Pembelajaran Penggunaan Metode Becerita Menggunakan Panggung Boneka Dapat Memberikan Pengaruh Terhadap Kemampuan Menyimak Anak.

\section{HASIL DAN PEMBAHASAN}

\section{Pembahasan Hasil Penelitian}

Penelitian Ini Dilakukan Di Taman Kanak-Kanak Negeri Pembina Hanau Dipembuang Hulu 1 Kecamatan Hanau Kabupaten Seruyan Yang Berlokasi Di Jalan Baktri Entong Pembuang Hulu 1 Kecamatan Hanau, Kalimatan Tengah. Subjek Penelitian Ini Yaitu Anak Usia 5-6 Tahun Di Kempok B1 Sebanyak 18 Orang. Sebelumnya peneliti telah melakukan wawancara dan observasi awal di lapangan untuk mengetahui bagaimana kemampuan menyimak anak di taman kanak-kanak tersebut.Penggunaan media bercerita menggunakan panggung boneka diperoleh dengan melakukan observasi terhadap aktivitas anak mengulang kalimat yang lebih kompleks, menceritakan kembali dengan kosakata anak sendiri, melakukan beberapa perintah secara bersamaan, kegiatan treatment dilakukan 8 kali pertemuan yang bertema hewanhewan dengan cerita yang berbeda-beda.

Peneliti mengingatkan anak-anak tentang pembelajaran dengan tema: hewanhewan. Setiap hari hewan yang digunakan berbeda-beda dari hari ke-1 sampai hari ke-8.

Setelah melakukan pre-test dan treatment, peneliti melakukan post-test. Berdasarkan hasil uji-t diketahui rata-rata nilai pre-test 96 setelah dilakukan post-test menjadi 121 sehingga peningkatan sebesar 25. Selanjutnya berdasarkan uji-t diperoleh hitungan nilai $t_{\text {hitung }}=4,181$ nilai at tabel dengan df 17 pada taraf 5\% adalah 2,110 menunjukkan jika $t_{\text {hitung }}>t_{\text {tabel, }}$ maka $\mathrm{H}_{\mathrm{a}}$ diterima, dan $\mathrm{H}_{\mathrm{o}}$ ditolak terjadi Pengaruh Metode Bercerita Menggunakan Panggung Boneka Terhadap Kemampuan Menyimak Anak Pada Kelompok B1 di TKN Pembina Hanau Dipembuang Hulu 1 Kecamatan Hanau Kabupaten Seruyan. Berdasarkan hal tersebut terdapat makna bahwa Pembelajaran Penggunaan Metode Becerita Menggunakan Panggung Boneka Dapat Memberikan Pengaruh Terhadap Kemampuan Menyimak Anak.

Metode bercerita adalah cara penyampainkan atau penyajikan materi pembelajaran secara lisan dalam bentuk cerita dari guru kepada anak didik Taman Kanak-kanak. Panggung boneka adalah merupakan suatu tempat yang digunakan untuk 
mementaskan atau menampilkan suatu cerita dengan tokoh-tokoh boneka yang memerankannya. Pengaruh ini didukung oleh sejumlah teori yang menjadi landasan penelitian ini. Upaya untuk mengembangkan petensi kemampuan anak berbahasa melalui pendengaran dan kemudia menuturkannya kembali dengan tujuan melatih keterampilan dalam bentuk mendengarkan.

Berdasarkan hasil dari penelitian anak kelompok B1 yang dianalisis menggunakan uji-t di peroleh $t_{\text {hitung }}=4,181>t_{\text {tabel }}=2,110$. Dengan demikian kegiatan bercerita menggunakan panggung boneka memiliki pengaruh yang signitidikan terhadap peningkatan kemampuan menyimak anak kelompok B1 taman kanak-kanak negeri pembina hanau pembuang hulu 1 kecamtan hanau kabupaten seruyan. Hal tersebut dapat dilihat dari hasil $t_{\text {hitung }}$ lebih besar dari pada tabel yang berarti hipotensi alternatif dapat diterima, yaitu "Ada pengaruh yang positif dan signifikan antara penggunaan media panggung boneka terhadap Kemampuan Menyimak Anak Kelompok B1 Tk Negeri Pembina Hanau Di Desa Pembuang Hulu Kecamatan Hanau Kabupaten Seruyan tahun ajaran 2018/2019”.

\section{KESIMPULAN}

Berdasarkan analisis data perhitungan pengujian hipotesis dengan menggunakan uji-t maka dapat disimpulkan bahwa thitung sebesar 4,181sedangkan harga $t_{\text {tabel }}$ dengan taraf signifikan 5\% dan db $(\mathrm{N}-1=18-1=17)$ maka nilai $t_{\text {tabel }}$ adalah 2,110. Dengan demikian, dapat diketahui bahwa $t_{\text {hitung }}>t_{\text {tabel }}$ yaitu $t_{\text {hitung }}=4,181>t_{\text {tabel }}=2,110$. Jika $t_{\text {hitung }}$ $>t_{\text {tabel, }}$ maka $\mathrm{H}_{\mathrm{a}}$ dapat diterima, dan $\mathrm{H}_{\mathrm{o}}$ ditolak, artinya ada pengaruh yang positif antara penggunaan media panggung boneka terhadap Kemampuan Menyimak Anak Kelompok B1 Tk Negeri Pembina Hanau Di Desa Pembuang Hulu Kecamatan Hanau Kabupaten Seruyan tahun ajaran 2018/2019. 


\section{DAFTAR PUSTAKA}

Al-Tabany, Trianto Ibnu Badar. 2011. Desain Pengembangan Pembelajaran Tematik Bagi Anak Usia Dini TK/RA \&Anak Usia Kelas Awal SD / MI. Jakarta : Prenadamedia Group.

Chaer, Abdul. 2011. Tata bahasa praktis bahasa indonesia. Jakarta. Rineka cipta.

Dhieni, Nurbaina Dkk. 2005. Metode Pengembangan Bahasa. Jakarta : Universitas Terbuka.

Fadlillah, Muhammad. 2014. Desain Pembelajaran PAUD. Jogjakarta : Ar- Ruzz Media.

Hasan, Maimunah. 2009. Pendidikan Anak Usia Dini. Jogjakarta. Diva Press.

Indrawan, Rully Dk. 2016. Metode Penelitian Kuantitatif, Kualitatif, dan Campuran Untuk Manajemen, Pembangunan, Dan Pendidikan. Bandung : PT. Refika Aditama.

Juliandari, Ni Komang, I Nyoman Wirya, Nice Maylani Asril. 2015. Penerapan Metode Bercerita Dengan Media BonekaTangan Untuk Meningkatkan Kemampuan MenyimakPada Anak. Jurnal, E-Journal Pg Paud Universitas Pendidikan GaneshaJurusan Pendidikan Guru Pendidikan Anak Usia Dini (Vol. 3 No. 1 Tahun 2015). Universitas Pendidikan Ganesha Singaraja, Indonesia

Kurniawati, Lut Putu Ria, Luh Ayu Tirtayani, I Wayan Darsana. 2018. Pengaruh Metode Bercerita Terhadap Kemampuan Menyimak Pada Anak Kelompok B Di Paud Gugus Anggrek, Kuta Utara. Jurnal, e-Journal Pendidikan Anak Usia Dini Universitas Pendidikan GaneshaJurusan Pendidikan Guru Pendidikan Anak UsiaDini (Volume 6 No. 1 Tahun 2018) Universita Pendidikan Ganesha.

Latif, Mukhtar Dkk. 2013. Orientasi Baru Pendidikan Anak Usia Dini. Jakarta : Kencana.

Madyawati, Lilis. 2016. Strategi Pengembangan Bahasa Pada Anak. Jakarta : Kencana.

Mursid. 2015. Pengembangan Pembelajaran PAUD. Bandung : PT. Remaja Rosdakarya.

Mustafidah, Tukiran Hidayati Taniredja. 2014. Penelitan Kuantitatif. Bandung : Alfabeta.

Peraturan Materi Pendidkan Dan Kebudayaan Republik Indonesia Nomor 137 Tahun 2014 Tentang Kurikulum 2013 Pendidikan Anak Usia Dini.

Peraturan Materi Pendidkan Dan Kebudayaan Republik Indonesia Nomor 146 Tahun 2014 Tentang Kurikulum 2013 Pendidikan Anak Usia Dini.

Rahmad, Abdul, Ertiwi Mamonto. 2016. Pengaruh Metode Bercerita Terhadap Kemampuan Menyimak Anak Di Kota Seletan Gorontalo. Jurnal, Journal Of Nonformal Education And Community Empowerment. Universitas Negeri Gorontalo. Jurusan Pendidikan Luar Sekolah.

Sujiono, Yuliani Nurani. 2013. Konsep Dasar Pendidikan Anak Usia Dini. Jakarta : PT. Indeks.

Sugiyono. 2015. Statistika untuk penelitian. Bandung. Alfabeta.

Sandjaja, B Dk. 2006. Panduan Penelitian. Jakarta : Prestasi Pustakaraya.

Sanjaya, H Wina. 2013. Penelitian Pendidikan Jenis, Metode Dan Prosedur. Jakarta : Kencana.

Solihati, Efektifitas Media Panggung Boneka Untuk Meningkatkan Kemampuan Bercerita Pada Anak Usia Dini. Di Unduh Pada Tanggal 10 April 2019

Sa'diah, Yuli, Musrifatus. Pada tahun 20017. Penggunaan Media Panggung 
Boneka Untuk Meningkatkan Pemahaman Materi Kedudukan Dan Peran Anggota Keluarga Pada Mata Pelajaran Ips Kelas Ii B Mi Miftahul Ulum Kesamben Wetan Driyorejo Gresik. Di unduh pada tanggal 10 april 2019.

Wiyani, Novan Ardy. 2016. Konsep Dasar PAUD. Jogjakarta : Gava Media 